\title{
AC 2008-602: A LEADERSHIP TEAM FOR TECHNICAL STUDENTS
}

\section{Dorene Perez, Illinois Valley Community College}

James Gibson, Illinois Valley Community College

Jim Gibson, Program Director/Instructor of Electronics at IVCC, is co-Principal Investigator for NSF Grant \#0501885. A former State Director of the Illinois Association of Electronics and Electrical Educators, he has extensive industrial experience. In 2005, he was named Outstanding Faculty by the National Association of Industrial Technology. He holds an M.S. and B.S. in Industrial Technology, minor in chemistry, from Illinois State University.

\section{Rose Marie Lynch, Illinois Valley Community College}

Rose Marie Lynch, communications instructor at IVCC, is co-Principal Investigator for NSF Grant \#0501885. She is co-leader of IVCC's Tech Prep Team and former co-director of the Center for Excellence in Teaching, Learning and Assessment. In 1999, she was named Illinois Professor of the Year by the Carnegie Foundation. She holds a Ph.D. in English from Ball State University. 


\section{A Leadership Team for Technical Students}

A leadership team at Illinois Valley Community College (IVCC) provides technical students with opportunities for personal and professional growth and provides the college with enthusiastic and capable students to assist with recruiting and mentoring. The team was established in 2006 as part of a National Science Foundation grant initiative to provide academic support to technical students and to assist in recruiting high school students into technical programs. Only two years later, the team has evolved into much more than the organizers imagined, as a result of the team members taking ownership of their activities.

Students are recommended for the team by high school industrial education instructors and IVCC engineering design, electronics and manufacturing instructors. A committee of IVCC instructors selects students for the team based on attitude, commitment and work ethic, willingness to help others and leadership potential. The selected students agree to participate in certain activities to earn a small stipend. To improve their success in college and their leadership skills, they are offered free enrollment in a college orientation course.

In the first year, the students were encouraged to define their roles. They demonstrated their initiative by arranging visits to their high schools to talk with industrial education teachers and students. One team member applied for and received an award to attend the NSF ATE Principal Investigators Conference in Washington D.C., and he presented a showcase there.

In the second year, the team doubled in size. In addition to expanding their recruiting roles, they decided to establish an identity by adopting a name, Leaders in Industrial Technology Engineering Working for Advancement in Vocational Education or LITE WAVE, and designing a team logo. Team members spoke to community organizations about technical programs at IVCC, served as members of a technical curriculum advisory board, assisted with career and job fairs, and mentored other technical students. Five members of the team gave a poster presentation about their team activities at the American Society for Engineering Education Illinois/Indiana Section Conference in Indianapolis in spring 2007. In the end-of-year assessment, team members recommended more team meetings and election of team officers to provide more structure. Two members of that team, currently sophomores and continuing on the team, received an award to attend the NSF ATE Principal Investigators Conference in Washington D.C. in October 2007 and to present a showcase on team activities.

The early success of this initiative indicates the leadership potential of promising technical students can be identified, nurtured and developed through simple, cost effective and replicable efforts. The payoffs for those efforts are a pool of enthusiastic, capable ambassadors for the college, and graduates prepared to utilize their leadership skills in the workplace. 